\title{
Price Promotion of Organic Foods and Consumer Demand
}

2

3

4 Authors:

5 Danhong Chen ${ }^{1}$, Edward C. Jaenicke ${ }^{2}, \mathrm{Ji} \mathrm{Yan}^{3}, \mathrm{Kun} \mathrm{Tian}^{4}$, and Rodolfo M. Nayga

6

7

8 Affiliations:

$9 \quad{ }^{1}$ Assistant Professor of Agribusiness, School of Agricultural Sciences, Sam Houston State

10 University

11 2Professor of Agricultural Economics, Department of Agricultural Economics, Sociology, and

12 Education, The Pennsylvania State University

$13{ }^{3}$ Associate Professor in Marketing, Durham University Business School, Durham University

$14{ }^{4}$ Lecturer in Marketing, Norwich Business School, University of East Anglia

$15{ }^{5}$ Professor and Head, Department of Agricultural Economics, Texas A\&M University

Corresponding Author:

Dr. Danhong Chen, Ph.D.

School of Agricultural Sciences

Sam Houston State University

Box 2088, Huntsville, Texas 77341

Phone: (936) 294-1214

Fax: (936) 294-1232

E-mail: $\underline{\text { dchen@shsu.edu }}$

27 


\section{Price Promotion of Organic Foods and Consumer Demand}

Abstract:

Existing studies have examined the demand elasticities for organic products only in select categories, and their results for consumers' sensitivity to price changes are inconsistent. Evidence regarding the effects of price promotions on the demand for organic foods versus nonorganic foods is scarce. This study aims to 1) examine the own-price elasticities of organic foods versus non-organic counterparts both with and without a promotion in a variety of product categories, and 2) investigate how the distinctive promotion effects between organic and non-

37 organic counterparts depend on food category features. Using purchase data for 36 food categories from the 2015 Nielson Consumer Panel, we find differential own-price elasticities for organic and non-organic foods, regardless of whether the product is purchased with a promotion. When the products are purchased with a promotion, we find stronger price promotion effects of organic virtues than non-organic virtues and weaker price promotion effects of organic vices

42 than conventional vices. Price promotions of organic foods are more likely to induce health-

43 conscious consumers to switch from conventional purchases to organic purchases in virtues.

44 Keywords: organic virtues, organic vices, demand elasticity 


\section{Introduction}

The U.S. organic industry has seen rapid growth nearly every year since the 1990s,

47 organic food sales reached $\$ 50.1$ billion in 2019 , accounting for $5.8 \%$ of total food sales (OTA,

48 2020). A multitude of studies have investigated the organic price premiums and demand

49 elasticities for organic foods (Jaenicke and Carlson, 2015, Yiridoe et al., 2005). However, their

50 results are mixed regarding consumers' sensitivity to price changes of organic foods

51 (Aschemann-Witzel and Zielke, 2017, Rödiger and Hamm, 2015).

52 Existing studies have estimated the demand elasticities for organic products only in select

53 product categories (Rödiger and Hamm, 2015). The estimated own-price elasticities for organic

54 milk are much higher in magnitude among certain studies (Jonas and Roosen, 2008, Lopez and

55 Lopez, 2009) than others (Bernard and Bernard, 2009, Schröck, 2012). Glaser and Thompson

56 (2000) find that the demand for organic milk is highly elastic, but it declined over the study

57 period from November 1996 to December 1999. This concords with another finding of elastic

58 demand for organic milk, based on retail scanner data from March 1997 to February 2002 (Dhar

59 and Foltz, 2005). Compared with private label milk, the own-price elasticity for organic milk is

60 higher in magnitude, and the demand for more expensive specialty milk is more elastic,

61 indicating that consumers may abandon the pricy milk options when their prices rise (Lopez and

62 Lopez, 2009). While two studies show more elastic demand for organic fruits and vegetables

63 than their non-organic counterparts (Fourmouzi et al., 2012, Kasteridis and Yen, 2012), another

64 study finds that this conclusion does not always hold for organic vegetables (Zhang et al., 2011).

65

The variation in product features may be a contributing factor to the inconsistent demand

66 elasticities for organic foods (Aschemann-Witzel and Zielke, 2017). However, to our knowledge,

67 evidence regarding such moderating factors is scarce. Based on store-level data for multiple 
68 product categories, Bezawada and Pauwels (2013) find that the sales elasticity to regular price

69 change is greater for organic than conventional foods. They also show that consumer sensitivity

70 to regular price changes is greater in categories that have higher purchase frequencies, are so-

71 called virtue products, and are less processed (produce, dairy, meat, and poultry), but it is lower

72 for categories with higher organic price premiums.

73 Due to inconsistent findings of demand elasticities and the lack of evidence regarding

74 consumers' responses to price promotions of organic foods versus non-organic foods, the first

75 objective of this study is to investigate the own-price demand elasticities of organic foods versus

76 non-organic counterparts both with and without a promotion in a wide range of product

77 categories. The second objective of this study is to examine how consumers' differential

78 responses to price promotions of organic foods versus non-organic counterparts depend on food

79 category features, including the vice/virtue classification, whether the food is in a fresh category,

80 the organic price premiums, and purchasing shares of organic foods in a product category. These

81 factors are discussed in detail in the literature review section.

82

83

84

85

86

87 in the future (Wertenbroch, 1998). Past studies have applied the concepts of vices and virtues in

88

89

90

\section{Literature Review}

Relative vices refer to products that offer immediate hedonic experience but may lead to adverse long-term consequences (e.g., negative health problems). Relative virtues are products that provide less gratifying experience in the short-run but contribute to less negatives outcomes two ways. One line of studies describes pairs of foods as relative vices and virtues (ParreñoSelva et al., 2014, Yan et al., 2017). For example, alcohol-free beer and alcoholic beer are considered relative virtues and vices, respectively, in Parreño-Selva et al. (2014). The other line 
91 of studies defines healthy and unhealthy food categories as relative virtues and vices (Liu et al.,

92 2015, Mishra and Mishra, 2011, van Doorn and Verhoef, 2011). For instance, baby carrots and

93 potato chips represent pure virtues and pure vices, respectively, in Liu et al. (2015).

94 Consumers buy organic products because of their perceived benefits, such as nutrition

95 value, taste, and environmental protection (Paul and Rana, 2012, Pino et al., 2012). In a previous

96 experimental study, 115 participants were asked to evaluate the nutrition and taste of three paired

97 food samples, including cookies, potato chips, and yogurt (Lee et al., 2013). One group of foods

98 in the pair was labeled as "regular" and the other group was labeled as "organic", even though

99 the two groups were actually identical, and both of them were organically produced. Participants

100 perceived the foods with organic labels to be more nutritious, have a higher level of fiber, and

101 have lower levels of fat and calorie than the foods labeled as "regular". Although organic foods

102 are perceived to be healthier than their non-organic counterparts, whether an organic label

103 induces higher food consumption may depend on the food type, especially the vice/virtue

104 classification. Lee et al. (2018) find that an organic label is associated with increased

105 consumption of a relative vice food but reduced intake of a relative virtue food.

106 Consumers' perceptions of quality, healthfulness, and environmental benefits may differ

107 between virtues and vices, leading to differential willingness-to-pay (WTP) for vice and virtue

108 foods. Based on multiple studies, van Doorn and Verhoef (2011) find that an organic claim's

109 positive effect of prosocial benefits on WTP is stronger for vices than virtues, whereas the

110 positive effect of quality perception on WTP is stronger for virtues than vices. There is also

111 evidence showing that consumers are willing to pay a higher premium in fresh categories such as

112 fruits and vegetables (Gil et al., 2000). 
Previous studies have found distinct price promotion effects in relative vices and virtues.

114 Parreño-Selva et al. (2014) show that consumers are more sensitive to price promotions of vice

115 products (alcoholic beer) than virtue products (non-alcoholic beer). Consistent with this finding,

116 Yan et al. (2017) also find that the price promotion effects are stronger for relative vice products

117 than virtue products (i.e., "low fat", "low sugar", "low calorie") in crisps and beer. However, this

118 finding is reversed in different food categories. That is, the price promotion effects are stronger

119 for relative virtue products than vice products in baked beans and fresh fruit juices (Yan et al.,

120 2017).

121

In addition to the vice/virtue nature, whether consumers are more sensitive to price

122 changes of organic foods than non-organic counterparts may also depend on a number of other

123 food category factors such as price premium and share of purchases (Bezawada and Pauwels,

124 2013). For example, Sridhar et al. (2012) find that the share of organic purchases varies across

125 product categories, with less processed categories being the highest, and Van Doorn and Verhoef

126 (2015) find that consumers are more likely to purchase organic foods in fresh and virtue

127 categories.

128 Three review studies unequivocally conclude that price is the major barrier to organic

129 purchases (Aertsens, 2009, Aschemann-Witzel and Zielke, 2017, Hughner et al., 2007). There

130 are only a few studies that find other factors such as availability, information/knowledge, and

131 product assortment as the primary inhibitors, but they rely on data from markets in early stages

132 of development or from habitual consumers in mature markets (Aschemann-Witzel and Zielke,

133 2017). Organic price premiums and promotion intensity are negatively associated with shares of

134 organic purchases (Van Doorn and Verhoef, 2015). 
Studies of WTP for organic products have yielded varied estimates ranging from $0 \%$ to

136

137

138

139

140

141

142

143

144

145

146

147 (Hu et al., 2011).

148

149

150

151

152

153

154

155

156

157

over 100\% (Aschemann-Witzel and Zielke, 2017). The great variation can be attributed to

several factors, including product category (product-specific features), consumer segment

(consumer-specific characteristics), and labeling practice. For instance, a higher percentage of

consumers in Greece are willing to pay a price premium of $30 \%$ or more for organic fruits and

vegetables compared to other product categories (Krystallis, 2005). Hamzaoui-Essoussi and

Zahaf (2012) divide consumers into three segments, including true organic food consumers,

sporadic organic food consumers, and inexperienced organic food consumers. They find that true

organic food consumers are willing to pay for the highest price premiums, whereas

inexperienced organic food consumers are willing to pay for the lowest for all product categories

(Hamzaoui-Essoussi and Zahaf, 2012). Consumers are willing to pay more for jams labeled as

" $100 \%$ organic", but the "95\% organic" seal is not significantly associated with a price premium

Sociodemographic characteristics rarely fall in the scope of the primary research

question, but they are also important predictors for organic food purchases. Studies that are based on large sample sizes (e.g., consumer panel data) and rigorous research methods tend to confirm a positive relationship between household income and organic food choices (Jonas and Roosen, 2008, Ngobo, 2011, Schröck, 2012, Smith et al., 2009a). Educational attainment has been considered simultaneously with the income level to measure social class (Loureiro and Hine, 2002). A higher level of education is often associated with a higher propensity to shop for organic foods (Ngobo, 2011, Smith et al., 2009a, Wier et al., 2008). The presence of children is not always found to increase the probability of patronizing organic foods (Jonas and Roosen, 2008), but it tends to have a positive impact among families with young children (Smith et al., 
2009a, Wier et al., 2008). On the one hand, parents perceive organic foods as healthier alternatives to conventional counterparts (Smith et al., 2009a). On the other hand, a larger number of children and household size may impose a budget constraint that hinders organic food purchases (Schröck, 2012).

\section{Data and Modeling Approach}

The Nielsen Consumer Panel data track all the food and non-food purchases of a panel of households representative of the population in the United States. The households use in-home scanners to record their purchases from anywhere. Using data from the 2015 Nielsen Consumer Panel, we analyze consumer responses to price promotions of organic and non-organic products in 36 food categories. Similar to previous studies (Liu et al., 2015, Mishra and Mishra, 2011), relatively healthy and unhealthy foods as considered as relative virtues and vices, respectively, in this study. A total number of 17,494,986 purchases (observations) are included in our analysis. To estimate the own-price demand elasticities of organic versus non-organic foods both with and without a promotion (objective 1), we use the following model specification:

$$
\begin{aligned}
& \ln Q_{i j t}=\beta_{0}+\beta_{1} \ln P R I C E_{i j t}+\beta_{2} O R_{i j t}+\beta_{3} P R O_{i j t}+\beta_{4} \ln P R I C E_{i j t} * O R_{i j t}+\beta_{5} \ln P R I C E_{i j t} \\
& * P R O_{i j t}+\beta_{6} O R_{i j t} * P R O_{i j t}+\beta_{7} \ln P R I C E_{i j t} * O R_{i j t} * P R O_{i j t}+\beta_{8} C O L L E G E_{j} \\
& +\beta_{9} F_{U L L T I M E}+\beta_{10} I_{N C O M E_{j}}+\beta_{11} \operatorname{SIZE}_{j}+\beta_{12} \text { CHILDREN }_{j} \\
& +\beta_{13} M A R R I E D_{j}+\varepsilon_{i j t}
\end{aligned}
$$

$$
\text { PriceElasticity }= \begin{cases}\beta_{1} & \text { if } O R_{i j t}=0 \text { and } P R O_{i j t}=0 \\ \beta_{1}+\beta_{4} & \text { if } O R_{i j t}=1 \text { and } P R O_{i j t}=0 \\ \beta_{1}+\beta_{5} & \text { if } O R_{i j t}=0 \text { and } P R O_{i j t}=1 \\ \beta_{1}+\beta_{4}+\beta_{5}+\beta_{7} & \text { if } O R_{i j t}=1 \text { and } P R O_{i j t}=1\end{cases}
$$

$\ln Q_{i j t}$ refers to the natural logarithm of the quantity of product $i$ purchased at time $t$ for household $j$, measured as ounces. Each regression is conditional on a positive purchase of the 
179 product. $O R_{i j t}$ is a dummy variable indicating whether the product is organic. $\ln P R I C E_{i j t}$ indicates the natural logarithm of the unit price of product $i$ at time $t$, measured as dollars per ounce. For each purchase, coupon value is deducted from the total price paid by consumers to generate the final price that consumers pay. We then calculate the unit price per ounce by dividing the total price by the total number of ounces. $P R O_{i j t}$ indicates if a coupon is used or if there is an in-store sale for the purchase. COLLEGE $E_{j}$ indicates whether the household head has a college degree. FULLTIME $E_{j}$ is a dummy variable indicating whether the household head is 186 employed fulltime. INCOME is a categorical variable showing the income level of a household. $S I Z E_{j}$ represents the household size. $C H I L D R E N_{j}$ and $M A R R I E D_{j}$ are both dummy variables indicating whether a household has children and whether the household head is married, respectively. $\varepsilon_{i j t}$ is the residual term. The regression is estimated by OLS, and the standard errors are clustered by the household identifier. of organic foods and non-organic foods without a promotion. The own-price elasticities of organic foods and non-organic foods with a promotion are represented by $\beta_{1}+\beta_{4}+\beta_{5}+\beta_{7}$ and $\beta_{1}+\beta_{5}$, respectively. The differential price promotion effects are captured by $\beta_{4}+\beta_{7}$. When $\beta_{4}+\beta_{7}<0$, the own-price elasticity of organic foods is higher (in magnitude) than that of non-organic foods, suggesting stronger price promotion effects of organic products.

197 When $\beta_{4}+\beta_{7}>0$, the price promotion effects of organic foods are weaker than non-organic 198 foods. Corresponding with the second objective, the sign of $\beta_{4}+\beta_{7}$ is expected to be dependent 199 on a number of product category features that are reviewed in the literature review section. Following Van Doorn and Verhoef (2015), we classified the 36 food categories into 15

201 virtue foods, 13 vice foods, and 8 categories that are neither virtue nor vice. Two-sample t-tests 
202 are used to examine how the sign of $\beta_{4}+\beta_{7}$ differs among virtue/vice/neutral food categories, 203 and fresh/non-fresh food categories. Pearson's correlations are used to investigate the association 204 between differential promotion effects and organic price premiums, and the association between 205 differential promotion effects and share of organic purchases. Organic rice premium is measured 206 as the percentage difference in unit price between organic and conventional products in a product 207 category. Share of organic purchases is calculated as the number of organic purchases relative to 208 the total number of purchases in a food category.

\section{Results and Discussions}

Table S1 in the supplementary materials presents the characteristics of the 36 food

212 categories. In most food categories, organic versions of the product enjoy price premiums 213 ranging from $5.49 \%$ (baby food) to $297.67 \%$ (carbonated beverage). Our calculated price

214 premiums are consistent with previous studies. For example, the price premium of organic milk 215 is approximately $64 \%$, which is similar to the numbers estimated (60\% for manufacturer brands 216 and $75 \%$ for store brands) in Glaser and Thompson (2000). But it is lower than the price

217 premium estimated in Smith et al. (2009b). Using a hedonic model with baby food and store 218 characteristics as the explanatory variables for price, Maguire et al. (2004) find that consumers 219 are willing to pay 3 or 4 cents more per ounce for organic baby food, almost identical to our 220 calculation of 4 cents per ounce. Surprisingly, consumers pay lower prices for the organic 221 versions of the product in certain food categories such as canned seafood and desserts, after 222 deducting coupons from each purchase.

Almost all the purchasing shares of organic food are below $10 \%$, except for baby food.

224 Thirteen out of the 36 food categories have organic purchasing shares below 1\%. Consumers are 
most likely to buy the organic versions of two food categories — baby food and fresh produce, with organic purchasing shares equal to $17.56 \%$ and $9.97 \%$, respectively. The shares of organic purchases are generally higher in virtue categories than vice categories.

Table S2 in the supplementary materials demonstrates a series of coefficients estimated by OLS with clustered standard errors. The volume of each food purchase is significantly influenced by household demographic characteristics. Having a college degree, higher household income, larger household size, and being married are positively associated with the volume of each transaction in most of the food categories. In contrast, having a full-time job or children is significantly associated with smaller transaction volumes for most of the food categories.

As expected, the signs of $\beta_{4}$ and $\beta_{4}+\beta_{7}$ vary across the 36 food categories, indicating differential responses to price changes between organic products and non-organic products in various food categories, regardless of whether the product is purchased with a promotion or not. When $\beta_{4}+\beta_{7}<0$, the demand elasticity for organic food is higher (in absolute value) than that for non-organic food with a promotion. For instance, consumers are more responsive to price promotions of organic fresh produce than non-organic fresh produce. When $\beta_{4}+\beta_{7}>0$, the demand elasticity for organic food is lower (in absolute value) than that for non-organic counterparts with a promotion. For example, consumers are less sensitive to the price promotions of organic candy than non-organic candy.

The differential promotion effects $\left(\beta_{4}+\beta_{7}\right)$ between organic and non-organic foods by the virtue/vice status are depicted in Figure 1. $\beta_{4}+\beta_{7}$ is negative for most virtue foods, but it is positive for most vice foods. The mean of $\beta_{4}+\beta_{7}$ for virtue foods is -0.076 (Table 1 ), indicating stronger price promotion effects of organic virtues than non-organic virtues. In contrast, the mean of $\beta_{4}+\beta_{7}$ for vice foods is 0.105 (Table 1), suggesting stronger price promotion effects of 
non-organic vices than organic vices. The two means are significantly different from each other $(\mathrm{p}=0.002$ from a two-sample t-test). Other comparisons (virtue vs neither, vice vs neither, and fresh vs non-fresh) do not show statistical significance. Our findings are consistent with a previous study showing a higher sensitivity of organic promotions in virtue food categories (Bezawada and Pauwels, 2013) and with two studies (Fourmouzi et al., 2012, Kasteridis and Yen, 2012) that find higher own-price demand elasticities for organic fruits and vegetables than non-organic counterparts.

Our results are also likely consistent with prior research, Yan et al. (2017), that shows price promotion effects are stronger for relatively healthier alternatives (i.e., "low fat", "low sugar", "low calorie") than the original products in the virtue food categories (i.e., baked beans and fresh fruit juices), and that the price promotion effects are weaker for the relatively healthier options in the vice food categories (i.e., crisps and beer). While our results do not specifically account for healthiness attributes, a previous experimental study shows that consumers perceive organic foods to be lower in fat and higher in fiber, or relatively healthier than their non-organic counterparts (Lee et al., 2013). Therefore, our study lends further evidence in this regard.

The differential responses may be associated with the motivations of purchases in a virtue versus a vice food category. A relative virtue food category tends to offer long-term benefits, but less gratifying consumption experience. Because the organic attribute affects consumers' taste perception (Fillion and Arazi, 2002), the level of gratification, and therefore the relative virtue versus vice distinction may be affected by the attribute itself. For instance, sensory analysis indicates that organic orange juice tastes better than conventional orange juice (Fillion and Arazi, 2002). A more intense flavor in organically grown tomatoes have been reported in another sensory analysis (Zhao et al., 2007). Organic yogurt is perceived to be more flavorful and have 
271 better taste than regular yogurt (Lee et al., 2013). Besides, organic foods are often perceived to

272 be healthier than their conventional counterparts. Individuals may underestimate the caloric

273 content of organic foods (Lee et al., 2013), leading to less guilty in overconsumption. This

274 "health halo" effect of organic foods is reinforced in a virtue food category. In contrast, people

275 consume relatively vice food to get the immediate hedonic experience, with less emphasis on the

276 negative health effects in the long run. Wertenbroch (1998) suggests that the self-control

277 mechanism prevents consumers from buying large quantities of vice products in response to

278 price changes. As such, the health halo effect of an organic label may not work on a vice

279 product, since individuals who shop for vice foods are less concerned about the health benefits.

A previous study, Bezawada and Pauwels (2013), shows higher sensitivity to organic

281 promotions in food categories with higher purchase frequencies. However, Pearson's correlations

282 in this study do not show significant associations between differential promotion effects and

283 organic price premiums, and between differential promotion effects and share of organic

284 purchases. Nevertheless, price is one of the most important factors that prevent consumers from

285 buying organic products in all food categories (Vega-Zamora et al., 2014). As such, price

286 promotions may act as a catalyst that induces consumers to switch from conventional products to

287 organic products in virtues.

\section{Conclusion}

While many studies have estimated the demand elasticities of organic foods in selected

291 product categories, this study compares the own-price elasticities of organic foods with those of 292 their conventional counterparts both with and without a promotion in a wide range of product 293 categories. Rather than making an undiscriminating conclusion that consumers are less or more 
294 reactive to prices of organic products than those of conventional products, we conclude that it 295 depends on a number of product category features.

We find that the price promotion effects of organic foods are stronger than non-organic

297 counterparts in categories of virtue nature. Consumers are more likely to have a higher price

298 sensitivity for organic foods than non-organic counterparts in virtue categories. As reflected in

299 the higher organic purchase shares of virtue foods than vice foods, consumers are generally more 300 interested in purchasing organic foods in virtue categories. However, price is one of the most 301 important factors that prevent consumers from buying organic products, making a price discount 302 enticing for health-conscious consumers. They tend to perceive organic foods as healthier and 303 underestimate the caloric content of organic foods. This health halo effect of organic foods may 304 be reinforced in virtue categories, making the demand for organic virtues more price elastic. 305 Because of the negative health effects of vices, consumers tend to impose quantity constraints 306 and resist the temptation to consume more organic vices in response to price discounts. The findings from this study may help shed some light on the distinctive price promotion 308 strategies for organic virtues and vices. As the price promotion effects of organic foods are 309 stronger than non-organic counterparts in categories of virtue nature, intensive organic price 310 promotions may help convert conventional shoppers to organic consumers in such categories.

\section{Statement}

Researcher(s) own analyses calculated (or derived) based in part on data from Nielsen 314 Consumer LLC and marketing databases provided through the NielsenIQ Datasets at the Kilts 315 Center for Marketing Data Center at The University of Chicago Booth School of Business. 
The conclusions drawn from the NielsenIQ data are those of the researcher(s) and do not

reflect the views of NielsenIQ. NielsenIQ is not responsible for, had no role in, and was not

involved in analyzing and preparing the results reported herein.

\section{References}

Aertsens, J. 2009. Personal determinants of organic food consumption: a review. British Food Journal, 111, pp. 1140-1167.

Aschemann-Witzel, J. and Zielke, S. 2017. Can't Buy Me Green? A Review of Consumer Perceptions of and Behavior Toward the Price of Organic Food. Journal of Consumer Affairs, 51, pp. 211-251.

Bernard, J. C. and Bernard, D. J. 2009. What Is It About Organic Milk? An Experimental Analysis. American Journal of Agricultural Economics, 91, pp. 826-836.

Bezawada, R. and Pauwels, K. 2013. What is special about marketing organic products? How organic assortment, price, and promotions drive retailer performance. Journal of Marketing, 77, pp. 3151.

Dhar, T. and Foltz, J. D. 2005. Milk by any other name... consumer benefits from labeled milk. American Journal of Agricultural Economics, 87, pp. 214-228.

Fillion, L. and Arazi, S. 2002. Does organic food taste better? A claim substantiation approach. Nutrition \& Food Science, 32(4), pp. 153-157.

Fourmouzi, V., Genius, M. and Midmore, P. 2012. The Demand for Organic and Conventional Produce in London, UK: A System Approach. Journal of Agricultural Economics, 63, pp. 677-693.

Gil, J. M., Gracia, A. and Sánchez, M. 2000. Market segmentation and willingness to pay for organic products in Spain. The International Food and Agribusiness Management Review, 3, pp. 207-226.

Glaser, L. K. and Thompson, G. D. 2000. Demand for organic and conventional beverage milk. Hamzaoui-Essoussi, L. and Zahaf, M. 2012. Canadian Organic Food Consumers' Profile and Their Willingness to Pay Premium Prices. Journal of International Food \& Agribusiness Marketing, 24, pp. 1-21.

Hu, W., Batte, M. T., Woods, T. and Ernst, S. 2011. Consumer preferences for local production and other value-added label claims for a processed food product. European Review of Agricultural Economics, 39, pp. 489-510.

Hughner, R. S., Mcdonagh, P., Prothero, A., Shultz li, C. J. and Stanton, J. 2007. Who are organic food consumers? A compilation and review of why people purchase organic food. Journal of Consumer Behaviour, 6, pp. 94-110.

Jaenicke, E. C. and Carlson, A. C. 2015. Estimating and Investigating Organic Premiums for Retail-Level Food Products. Agribusiness, 31, pp. 453-471.

Jonas, A. and Roosen, J. 2008. Demand for milk labels in Germany: organic milk, conventional brands, and retail labels. Agribusiness, 24, pp. 192-206.

Kasteridis, P. and Yen, S. T. 2012. U.S. demand for organic and conventional vegetables: a Bayesian censored system approach. Australian Journal of Agricultural and Resource Economics, 56, pp. 405-425.

Krystallis, A. 2005. Consumers' willingness to pay for organic food: Factors that affect it and variation per organic product type. British Food Journal, 107, pp. 320-343.

Lee, W.-C. J., Shimizu, M., Kniffin, K. M. and Wansink, B. 2013. You taste what you see: Do organic labels bias taste perceptions? Food Quality and Preference, 29, pp. 33-39. 
Liu, P. J., Haws, K. L., Lamberton, C., Campbell, T. H. and Fitzsimons, G. J. 2015. Vice-Virtue Bundles. Management Science, 61, pp. 204-228.

Lopez, E. and Lopez, R. A. 2009. Demand for differentiated milk products: implications for price competition. Agribusiness, 25, pp. 453-465.

Loureiro, M. L. and Hine, S. 2002. Discovering niche markets: A comparison of consumer willingness to pay for local (Colorado grown), organic, and GMO-free products. Journal of Agricultural and Applied Economics, 34, pp. 477-487.

Maguire, K. B., Owens, N. and Simon, N. B. 2004. The price premium for organic babyfood: a hedonic analysis. Journal of Agricultural and Resource Economics, pp. 132-149.

Mishra, A. and Mishra, H. 2011. The Influence of Price Discount versus Bonus Pack on the Preference for Virtue and Vice Foods. Journal of Marketing Research, 48, pp. 196-206.

Ngobo, P. V. 2011. What Drives Household Choice of Organic Products in Grocery Stores? Journal of Retailing, 87, pp. 90-100.

OTA. 2020. COVID-19 will shape organic industry in 2020 after banner year in 2019 [Online]. Available: https://ota.com/news/press-releases/21328 [Accessed June 26 2020].

Paul, J. and Rana, J., 2012. Consumer behavior and purchase intention for organic food. Journal of consumer Marketing, 29(6), pp. 412-422.

Pino, G., Peluso, A.M. and Guido, G., 2012. Determinants of regular and occasional consumers' intentions to buy organic food. Journal of Consumer Affairs, 46(1), pp. 157-169.

Parreño-Selva, J., Mas-Ruiz, F. J. and Ruiz-Conde, E. 2014. Price promotions effects of virtue and vice products. European Journal of Marketing, 48, pp. 1296-1314.

Rödiger, M. and Hamm, U. 2015. How are organic food prices affecting consumer behaviour? A review. Food Quality and Preference, 43, pp. 10-20.

Schröck, R. 2012. The Organic Milk Market in Germany Is Maturing: A Demand System Analysis of Organic and Conventional Fresh Milk Segmented by Consumer Groups. Agribusiness, 28, pp. 274-292.

Smith, T. A., Huang, C. L. and Lin, B.-H. 2009a. Does price or income affect organic choice? Analysis of US fresh produce users. Journal of Agricultural and Applied economics, 41, pp. 731-744.

Smith, T.A., Huang, C.L. and Lin, B.H., 2009b. Estimating organic premiums in the US fluid milk market. Renewable Agriculture and Food Systems, 24(3), pp. 197-204.

Sridhar, K., Bezawada, R. and Trivedi, M. 2012. Investigating the Drivers of Consumer Cross-Category Learning for New Products Using Multiple Data Sets. Marketing Science, 31, pp. 668-688.

Van Doorn, J. and Verhoef, P. C. 2011. Willingness to pay for organic products: Differences between virtue and vice foods. International Journal of Research in Marketing, 28, pp. 167-180.

Van Doorn, J. and Verhoef, P. C. 2015. Drivers of and Barriers to Organic Purchase Behavior. Journal of Retailing, 91, pp. 436-450.

Vega-Zamora, M., Torres-Ruiz, F. J., Murgado-Armenteros, E. M. and Parras-Rosa, M. 2014. Organic as a Heuristic Cue: What Spanish Consumers Mean by Organic Foods. Psychology \& Marketing, 31, pp. 349-359.

Wertenbroch, K. 1998. Consumption self-control by rationing purchase quantities of virtue and vice. Marketing science, 17, pp. 317-337.

Wier, M., O'doherty Jensen, K., Andersen, L. M. and Millock, K. 2008. The character of demand in mature organic food markets: Great Britain and Denmark compared. Food Policy, 33, pp. 406421.

Yan, J., Tian, K., Heravi, S. and Morgan, P. 2017. The vices and virtues of consumption choices: price promotion and consumer decision making. Marketing Letters, 28, pp. 461-475. 
405

406

407

408

409

410

411

412

413
Yiridoe, E. K., Bonti-Ankomah, S. and Martin, R. C. 2005. Comparison of consumer perceptions and preference toward organic versus conventionally produced foods: A review and update of the literature. Renewable Agriculture and Food Systems, 20(4), pp. 193-205.

Zhang, F., Huang, C. L., Lin, B.-H., Epperson, J. E. and Houston, J. E. 2011. National Demand for Fresh Organic and Conventional Vegetables: Scanner Data Evidence. Journal of Food Products Marketing, 17, pp. 441-458.

Zhao, X., Chambers Iv, E., Matta, Z., Loughin, T. M. and Carey, E. E. 2007. Consumer sensory analysis of organically and conventionally grown vegetables. Journal of food science, 72, pp. S87-S91. 
416 Table 1. Differential Promotion Effects between Organic Foods and Non-organic Foods by

417 Category Features

\begin{tabular}{lrrrr}
\hline Category Features & Mean of $\boldsymbol{\beta}_{\boldsymbol{4}}+\boldsymbol{\beta}_{\mathbf{7}}$ & $\begin{array}{r}\text { Standard } \\
\text { Deviation }\end{array}$ & Minimum & Maximum \\
\hline Virtue & -0.076 & 0.150 & -0.311 & 0.254 \\
Vice & 0.105 & 0.132 & -0.127 & 0.396 \\
Neither & 0.060 & 0.210 & -0.183 & 0.518 \\
Fresh & 0.011 & 0.199 & -0.311 & 0.254 \\
Non-fresh & 0.022 & 0.173 & -0.262 & 0.518 \\
\hline
\end{tabular}

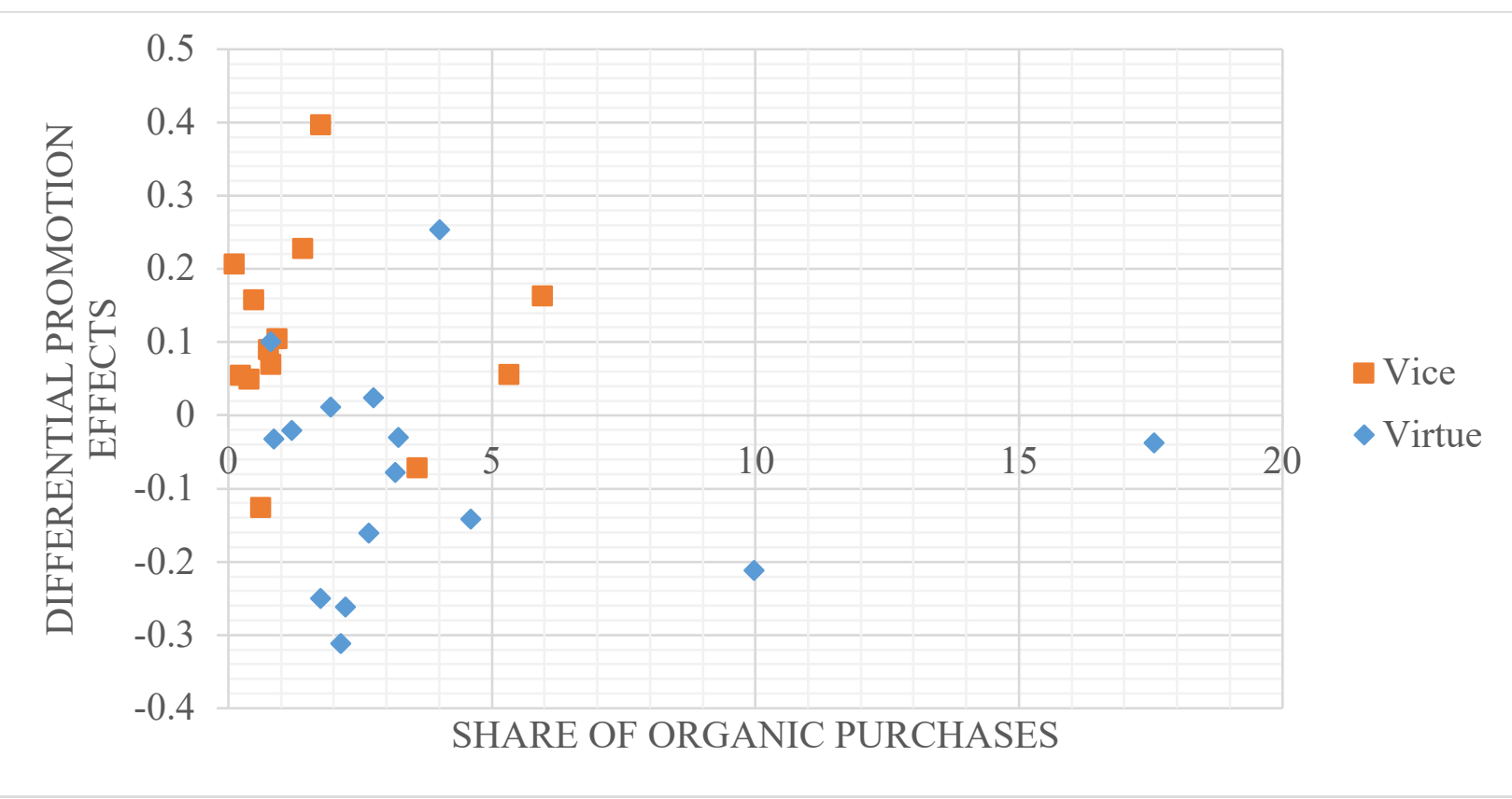

421 Figure 1. Differential Promotion Effects between Organic Foods and Non-organic Foods in 422 Virtue and Vice Food Categories 


\section{Supplementary Materials for}

\section{"Price Promotion of Organic Foods and Consumer Demand"}

Table S1. Characteristics of 36 Food Categories from the 2015 Nielsen Consumer Panel

\begin{tabular}{|c|c|c|c|c|c|c|c|c|}
\hline Type & $\begin{array}{l}\text { Product } \\
\text { Category }\end{array}$ & $\begin{array}{l}\text { Number of non- } \\
\text { organic food } \\
\text { purchases }\end{array}$ & $\begin{array}{c}\text { Unit } \\
\text { price of } \\
\text { non- } \\
\text { organic } \\
\text { foods } \\
(\$ / o z)\end{array}$ & $\begin{array}{c}\text { Number } \\
\text { of organic } \\
\text { food } \\
\text { purchases }\end{array}$ & $\begin{array}{c}\text { Unit } \\
\text { price of } \\
\text { organic } \\
\text { foods } \\
\text { (\$/oz) }\end{array}$ & $\begin{array}{c}\text { Price } \\
\text { premium } \\
\text { of organic } \\
\text { foods }\end{array}$ & $\begin{array}{l}\text { Purchasing } \\
\text { share of } \\
\text { organic } \\
\text { foods }\end{array}$ & $\begin{array}{c}\text { Fresh } \\
\text { Category }\end{array}$ \\
\hline Virtue & Baby food & 99,935 & 0.76 & 21,282 & 0.8 & $5.49 \%$ & $17.56 \%$ & No \\
\hline Virtue & Fresh produce & $1,115,614$ & 0.45 & 123,556 & 0.52 & $16.26 \%$ & $9.97 \%$ & Yes \\
\hline Virtue & Dried fruit & 198,517 & 0.47 & 9,573 & 0.91 & $95.66 \%$ & $4.60 \%$ & No \\
\hline Virtue & Milk & $1,588,951$ & 0.05 & 66,239 & 0.08 & $63.81 \%$ & $4.00 \%$ & Yes \\
\hline Virtue & Soup & 891,423 & 0.24 & 29,729 & 0.22 & $-7.95 \%$ & $3.23 \%$ & No \\
\hline Virtue & Cereal & $1,037,124$ & 0.25 & 33,932 & 0.31 & $22.41 \%$ & $3.17 \%$ & No \\
\hline Virtue & $\begin{array}{l}\text { Canned } \\
\text { vegetables }\end{array}$ & $1,087,632$ & 0.13 & 30,873 & 0.16 & $18.93 \%$ & $2.76 \%$ & No \\
\hline Virtue & $\begin{array}{l}\text { Canned/bottled } \\
\text { juice drinks }\end{array}$ & $1,277,947$ & 0.07 & 35,014 & 0.15 & $109.49 \%$ & $2.67 \%$ & No \\
\hline Virtue & $\begin{array}{l}\text { Frozen prepared } \\
\text { foods }\end{array}$ & $1,319,829$ & 0.3 & 29,958 & 0.49 & $64.71 \%$ & $2.22 \%$ & No \\
\hline Virtue & Yogurt & $1,162,122$ & 0.29 & 25,361 & 0.34 & $19.35 \%$ & $2.14 \%$ & Yes \\
\hline Virtue & $\begin{array}{l}\text { Ready-to-serve } \\
\text { prepared food }\end{array}$ & 663,487 & 0.28 & 13,111 & 0.34 & $21.20 \%$ & $1.94 \%$ & No \\
\hline Virtue & $\begin{array}{l}\text { Frozen } \\
\text { vegetables }\end{array}$ & 809,461 & 0.16 & 14,451 & 0.22 & $39.95 \%$ & $1.75 \%$ & No \\
\hline Virtue & $\begin{array}{l}\text { Packaged milk } \\
\text { and modifiers }\end{array}$ & 431,902 & 0.22 & 5,243 & 0.24 & $12.16 \%$ & $1.20 \%$ & No \\
\hline Virtue & Canned fruit & 313,962 & 0.14 & 2,734 & 0.26 & $90.29 \%$ & $0.86 \%$ & No \\
\hline Virtue & $\begin{array}{l}\text { Bread and baked } \\
\text { goods }\end{array}$ & $2,526,078$ & 0.19 & 20,444 & 0.23 & $21.04 \%$ & $0.80 \%$ & No \\
\hline Vice & Frozen desserts & 177,439 & 0.21 & 11,275 & 0.37 & $75.36 \%$ & $5.97 \%$ & No \\
\hline Vice & $\begin{array}{l}\text { Sugar and } \\
\text { sweeteners }\end{array}$ & 99,525 & 0.22 & 5,609 & 0.4 & $77.82 \%$ & $5.34 \%$ & No \\
\hline
\end{tabular}


Vice Table syrups and

82,337

0.18

3,067

0.53

$197.26 \%$

$3.59 \% \quad$ No

Vice $\begin{aligned} & \text { Non-carbonated } \\ & \text { soft drinks }\end{aligned}$

555,148

0.22

9,936

$0.19-12.96 \%$

$1.76 \% \quad$ No

Desserts,

Vice gelatins, and

$421,394 \quad 0.42$

6,065

$0.31 \quad-25.64 \%$

$1.42 \% \quad$ No

Vice

611,250

0.28

5,816

$0.56 \quad 97.22 \%$

$0.94 \% \quad$ No

Vice Cookies

820,141

0.32

6,792

0.53

$68.47 \%$

$0.82 \%$ No

Cot cheese, sour

Vice cream, and

496,451

0.17

3,889

$0.3 \quad 73.10 \%$

$0.78 \% \quad$ Yes toppings

Vice Ice cream and novelties

487,462

0.11

3,088

0.18

$61.70 \%$

$0.63 \% \quad$ No

Vice Candy

Vice Cheese

$$
1,801,804
$$

0.65

9,060

1.54

$137.24 \%$

$0.50 \% \quad$ No

Vice Carbonated

$1,674,938$

0.4

6,710

$0.75 \quad 90.61 \%$

$0.40 \% \quad$ Yes

$1,558,716$

0.08

3,793

0.33

$297.67 \%$

$0.24 \% \quad$ No

Vice Beer

229,140

0.15

290

0.33

$114.65 \%$

$0.13 \% \quad$ No

Neither Tea

284,308

0.43

11,696

0.39

$-9.05 \%$

$3.95 \%$ No

Spices,

Neither seasoning, and extracts

Neither Pasta

Neither Fresh meat

409,776

1.74

12,760

$5.5 \quad 215.20 \%$

$3.02 \% \quad$ No

418,612

0.13

8,863

$0.27 \quad 104.61 \%$

$2.07 \% \quad$ No

220,971

0.34

4,113

$0.52 \quad 55.27 \%$

$1.83 \% \quad$ Yes

Neither Coffee

339,937

0.57

4,562

0.69

$20.11 \%$

$1.32 \% \quad$ No

Neither Deli-packed

$1,486,815 \quad 0.38$

3,405

0.73

$91.17 \%$

$0.23 \% \quad$ Yes

Neither Baking mixes

361,305

0.15

799

0.26

$69.91 \%$

$0.22 \% \quad$ No

Neither

Canned seafood

232,525

0.62

184

$0.22 \quad-65.11 \%$

$0.08 \% \quad$ No 
Table S2. Coefficients Estimated by OLS with Clustered Standard Errors

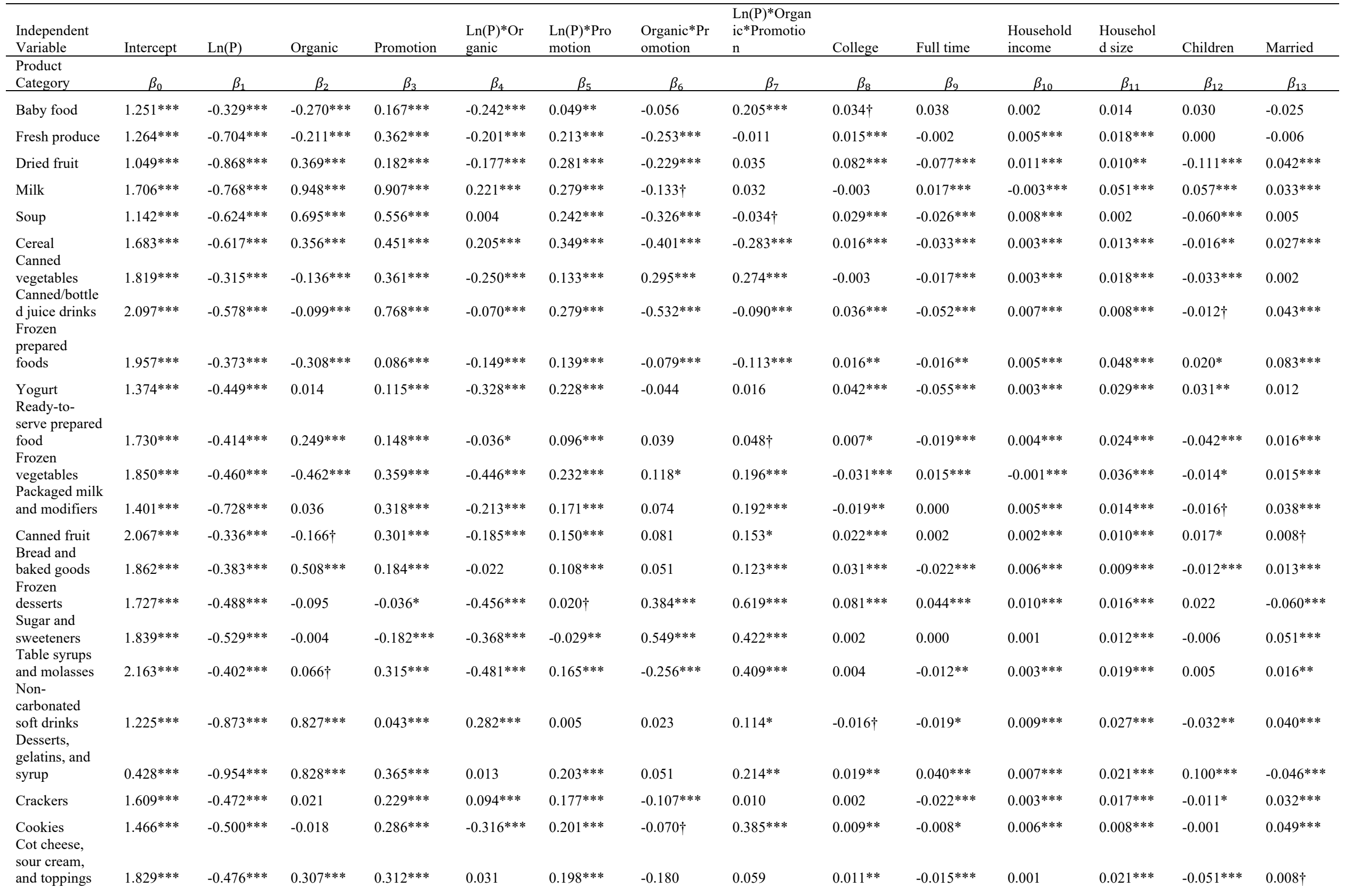




\begin{tabular}{|c|c|c|c|c|c|c|c|c|c|c|c|c|c|c|}
\hline $\begin{array}{l}\text { Ice cream and } \\
\text { novelties }\end{array}$ & $2.123 * * *$ & $-0.663 * * *$ & $0.927 * * *$ & $0.521 * * *$ & $0.356^{* * *}$ & $0.246^{* * *}$ & $-1.138 * * *$ & $-0.483 * * *$ & $-0.021 * * *$ & $-0.040 * * *$ & $-0.001 * * *$ & $0.018 * * *$ & -0.009 & $0.077 * * *$ \\
\hline Candy & $0.847 * * *$ & $-0.699 * * *$ & $0.065^{*}$ & $0.160 * * *$ & $0.150 * * *$ & $0.179 * * *$ & $-0.178^{* * *}$ & 0.007 & $0.029 * * *$ & $-0.029 * * *$ & $0.012 * * *$ & $-0.013 * * *$ & $-0.071 * * *$ & $0.059 * * *$ \\
\hline \multirow{2}{*}{$\begin{array}{l}\text { Cheese } \\
\text { Carbonated } \\
\text { beverages }\end{array}$} & $1.610 * * *$ & $-0.565 * * *$ & $0.128 * * *$ & $0.227 * * *$ & $0.238 * * *$ & $0.336^{* * *}$ & $-0.269 * * *$ & $-0.189 * * *$ & $0.006^{*}$ & $-0.010 * * *$ & $0.002 * * *$ & $0.029 * * *$ & $-0.024 * * *$ & $0.020 * * *$ \\
\hline & $2.306 * * *$ & $-0.518 * * *$ & $0.057^{* *}$ & $1.004 * * *$ & $0.230 * * *$ & $0.242 * * *$ & $-1.120 * * *$ & $-0.175^{* * *}$ & $-0.041 * * *$ & $-0.032 * * *$ & $0.006^{* * *}$ & $0.007^{*}$ & $-0.073 * * *$ & $0.117 * * *$ \\
\hline Beer & $2.310 * * *$ & $-0.854 * * *$ & $-0.187^{*}$ & $0.182 * *$ & $0.182 * *$ & 0.018 & -0.121 & 0.024 & $-0.104 * * *$ & $-0.050 \dagger$ & $0.018 * * *$ & -0.009 & -0.051 & $0.153 * * *$ \\
\hline \multirow{2}{*}{$\begin{array}{l}\text { Tea } \\
\text { Spices, } \\
\text { seasoning, and } \\
\text { extracts }\end{array}$} & $1.096^{* * *}$ & $-0.897 * * *$ & $0.131 * *$ & $0.309 * * *$ & $0.161 * * *$ & $0.138 * * *$ & $0.588 * * *$ & $0.356^{* * *}$ & $-0.022 *$ & $-0.077 * * *$ & $0.012 * * *$ & 0.003 & $-0.042 * *$ & $0.065^{* * *}$ \\
\hline & $0.720 * * *$ & $-0.745^{* * *}$ & $0.402 * * *$ & $-0.053 * * *$ & $-0.149 * * *$ & $0.061 * * *$ & $-0.259 * * *$ & $0.138^{* * *}$ & $0.045^{* * *}$ & $-0.023 * * *$ & $0.010 * * *$ & -0.002 & $-0.024 * * *$ & 0.007 \\
\hline Pasta & $2.044 * * *$ & $-0.278 * * *$ & $-0.084 * * *$ & $0.394 * * *$ & $-0.139 * * *$ & $0.191 * * *$ & $-0.300 * * *$ & $-0.044^{*}$ & -0.003 & 0.000 & $0.001 * * *$ & $0.015^{* * *}$ & $-0.011 * * *$ & 0.003 \\
\hline Fresh meat & $2.318 * * *$ & $-0.588 * * *$ & $0.317^{* * *}$ & $0.094 * * *$ & $-0.174 * * *$ & $0.132 * * *$ & $-0.163 * * *$ & $0.277^{* * *}$ & $-0.045^{* * *}$ & $0.017^{*}$ & $-0.004 * * *$ & $0.068 * * *$ & $-0.053 * * *$ & $0.030 * * *$ \\
\hline \multirow{2}{*}{$\begin{array}{l}\text { Coffee } \\
\text { Deli-packed } \\
\text { meats }\end{array}$} & $1.728 * * *$ & $-0.829 * * *$ & $0.319 * * *$ & $0.341 * * *$ & $0.187 * * *$ & $0.367 * * *$ & $-0.267 * * *$ & $-0.156 * * *$ & $-0.022 * *$ & $-0.045^{* * *}$ & $0.009 * * *$ & -0.005 & $-0.066^{* * *}$ & $0.105^{* * *}$ \\
\hline & $1.765^{* * *}$ & $-0.497 * * *$ & $0.212 * * *$ & $0.202 * * *$ & 0.048 & $0.208 * * *$ & $-0.255^{* * *}$ & 0.058 & 0.004 & $-0.025 * * *$ & $0.006 * * *$ & $0.020 * * *$ & $-0.044 * * *$ & $0.031 * * *$ \\
\hline \multirow{2}{*}{$\begin{array}{l}\text { Baking mixes } \\
\text { Canned } \\
\text { seafood }\end{array}$} & $1.700 * * *$ & $-0.423 * * *$ & $0.486 * * *$ & $0.466 * * *$ & $-0.092 *$ & $0.216^{* * *}$ & $-0.230 \dagger$ & -0.014 & $0.022 * * *$ & $-0.015 * * *$ & $0.005 * * *$ & $0.014 * * *$ & 0.003 & $0.024 * * *$ \\
\hline & $1.254 * * *$ & $-0.461 * * *$ & $0.749 * * *$ & $0.065 * * *$ & $0.459^{* * *}$ & $0.256^{* * *}$ & $-0.383 * * *$ & $-0.437 * * *$ & $0.019 * *$ & $-0.065^{* * *}$ & $0.009 * * *$ & $0.018 * * *$ & $-0.056^{* * *}$ & $0.034 * * *$ \\
\hline
\end{tabular}

